this year as the highest yielding variety of spring oat on the recommended list of the National Institute of Agricultural Botany.

One of the other special subjects of research at the Welsh Plant Breeding Station is the productivity of grassland. The aim is to achieve the highest possible efficiency in the conversion of light energy and soil nutrients to a form suitable for the ruminants which graze the grassland. There is scope for considerable increase in this efficiency, as measurements which have been made at Aberystwyth suggest.

Perennial ryegrass has been found to convert only about 3 per cent of the annual input of light energy to dry matter. The breeding programme at present involves selection of plants which absorb a greater proportion of the light which reaches them to give a more efficient use of the high light energy available in the summer. Also being selected are plants with leaves which expand more rapidly in the cold and low light intensity of the winter, when, with present varieties, the energy conversion can fall to $2 \cdot 6-2 \cdot 7$ per cent.

Comparison of the performance of prostrate and erect varieties of ryegrass in various conditions has shown that in the glasshouse, with a low light input (28 calories $/ \mathrm{cm}^{2} /$ day), the erect long-leaved varieties grow more rapidly than the prostrate short-leaved varieties. Although the prostrate varieties intercept more incoming light, the erect varieties convert more of it to solid matter. Incoming light seems to spread over a greater area in the erect varieties, so that it is used more efficiently. When these varieties were grown outside and cut periodically, the longer the intervals between cutting the higher was the yield. When cutting was frequent prostrate varieties were most productive, but with infrequent cutting the erect varieties were more productive.

\section{Pre-Roman Baldock}

\section{from a Correspondent}

BALDOCK, a small town in Hertfordshire, about 40 miles north of London, lies at the junction of three ancient roads-Icknield Way, Stane Street and a third unnamed road leading south to London. Predictably, in Roman times there was a considerable town on the site, perhaps covering as much as thirty acres. But three emergency excavations this year, conducted by the Ministry of Public Building and Works in anticipation of the destruction of the sites, have, as well as revealing more about Roman Baldock, proved that the town was an important Belgic centre before the Roman conquest.

At the beginning of this year, workmen uncovered the burial treasures of a person who must have been a British chieftain. The objects were quickly dispersed, but after some detective work they were all retrieved and the ministry mounted an excavation directed by Dr I. M. Stead. Neither the body nor evidence of cremation of the chieftain was discovered, but the grave objects, found in a shallow pit, compare very favourably with those unearthed at other "chieftains' burials" in southern Britain. They include elegant and typical firedogs, fragments of a large bronze cauldron with iron ring handles, fragments of two bronze bowls, and bronze strips, handles and decorative heads from a wooden, bronze-embellished bucket similar to the famous Aylesford bucket found in a contemporary burial in Kent. Whoever owned these objects was of considerable importance, most probably a minor chieftain, who must have enjoyed wines imported from the Roman Empire-a wine amphora was also found.

Close to this burial site, Dr Stead has excavated a three-quarter mile strip in Walls Field-a name probably corrupted from Wells Field-along the modern road A507, the Roman Stane Street. And at a site known as Brewery Field on the other side of this road, Mr Moss Eccardt, of Letchworth Museum, last week completed a four week emergency excavation.

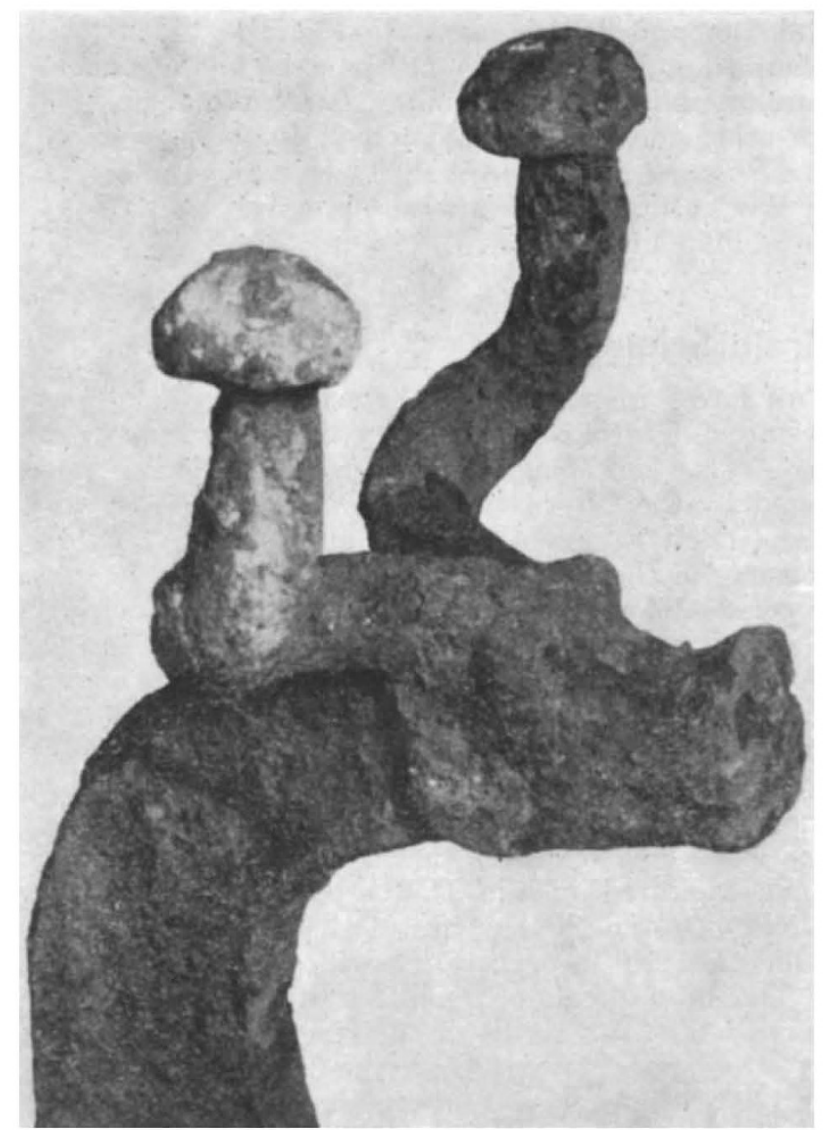

A detail of the pre-Roman iron firedogs found at Baldock.

The Brewery Field yielded more than 150 coins, 90 of them fourth century and the remainder from the first to third centuries. These coins provide firm evidence that Baldock, which was continuously occupied in the Iron Age, came under Roman rule soon after the conquest and remained a Romano-British town until the fifth century. Well over a hundred kilograms of pottery fragments, found at the Brewery Field, attest to the coin datings and indicate a flourishing trade.

The potsherds include Gaullish Samian ware with at least twenty different potters' stamps, which are particularly valuable for dating the site, a piece of green-glazed and decorated ware from St Remy, near Vichy, and Cranbeck ware from Yorkshire. The remains of the Roman buildings prove that they were the characteristic timber-framed wattle and daub structures with extensive flint-cobbled yards. The occurrence of one cobbled floor on top of an earlier one indicates that the buildings were rebuilt at least once; the extent of the cobbling, and the very 
uneven distribution of the coins, may mean that part of the site was a market place. Pieces of slag and other artefacts suggest the existence of ovens or, though less likely, furnaces for some local metal industry. Several bronze and iron objects including hairpins, keys, latches and pins have been found.

Because all the digs at Baldock have been emergency excavations, the layout of the Roman buildings and their relationship to Stane Street which, by elimination, is believed to be beneath the modern road, remain unclear. What the excavations have established, however, is the importance of Baldock even before the conquest, and the continuity of the pre-Roman and Romano-British occupation of the town, which occupied a key position at the crossing of the two ancient and important routes, one leading east-west, the other north-south. With luck, further excavations of a Roman cemetery in Walls Field, which the Ministry of Works intends to start in September, should throw more light on the period.

\section{Brain Sciences}

THE latest instalment of the world survey of brain sciences-a term covering everything from behavioural ecology to mathematical models of the brain-sponsored by the International Brain Research Organization (IBRO), covers research and teaching in brain sciences in the United States. The report, which was supervised by the Committec on Brain Science of the National Academy of Sciences-National Research Council, contains a state by state list of research groups and summaries of their research interests. Inevitably it is a little out of date and incompletesome groups failed to reply to questionnaires-but more than 4,000 individuals working in 373 laboratories are listed. Comparable surveys of 37 other countries have appeared in the IBRO bulletin published by UNESCO, and the surveys of the USSR and Mexico which are still in preparation will complete the series.

The brief breakdown of the survey in the report reveals that two thirds of the research groups receive at least some support from the Federal Government through its agencies, notably the National Institutes of Health. The graduate schools are apparently conducting 29 per cent of all brain science research, the medical and veterinary schools 25 per cent, and hospitals, research centres and Government and industrial laboratories account for the rest. The size of the research groups varies from individuals to groups of fifty or more people but there are only nine of these, including the Brain Research Institute of UCLA and groups at the Massachusetts Institute of Technology, the Rockefeller University, the National Institutes of Health and the National Institute for Mental Health. By contrast 249 of the 373 groups listed consist of between one and ten people. When analysed by departments, 32 per cent of the groups are in basic science, 18 per cent in clinical science, 14 per cent in behavioural science and 2 per cent in neurocommunications, which includes molecular biology of the brain.

The survey is essential reading for anyone who needs to discover what is happening in the field in the United States. The short descriptions of the research projects make it particularly valuable, and a limited number of copies are available on request from the National Academy of Sciences, Washington.

\section{Parliament in Britain}

\author{
by our Parliamentary Correspondent
}

\section{Diversification}

Mr Anthony Wedgwood Benn, Minister of Technology, gave details of the work undertaken by the Atomic Energy Authority under section 4 of the Science and Technology Act, 1965, which allows the AEA to diversify. He provided Sir Harry Legge-Bourke with. a list of the projects under way at the Atomic Weapons Research Establishment at Aldermaston. It includes space technology, the APACE computer centre, various forensic science projects for the Home Office, work on glass fibre reinforced plaster (sic) and work on dental materials. Diversification is clearly gathering pace; while total expenditure to March 31, 1968, had been

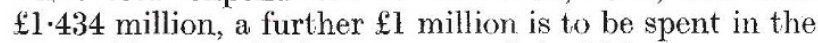
year 1968-69. (Written answer, July 22.)

\section{Channel Tunnel}

The Minister of Transport, Mr Richard Marsh, said that it should be possible to make an announcement shortly about progress on the Channel Tunnel. He had considered the proposals of three private groups, and an agreement with a selected financing group should be made by the end of the year. The issue was complicated, he explained, because the Government was trying to reconeile public and private investment in the project; he would try to make an announcement before the end of the recess, and promised that a debate would be held before a final decision was made. (Oral answer, July 24.)

\section{$300 \mathrm{GeV}$ Machine}

Mr Peter KirK (Saffron Walden) opened a short debate on the Government's decision not to support the $300 \mathrm{GeV}$ machine at CERN. The decision, he said, accorded ill with Mr. Wilson's constant references to a European technological community. British credibility in Europe had been lost, and the projects still supported with Europe, the Concorde and the European Airbus, were of doubtful profitability. Mr Tim Fortescue (Liverpool, Garston) agreed, but said that it was not too late for the Government to change its mind. Comparatively little expenditure was involved in the next three or four years. Replying, Mrs Shirley Williams, Minister of State at the Department of Education and Science, said that the decision was not simply a matter of money, though that was significant. There was also the length of the commitment, and the fact that the budget of the SRC would have had to grow at a rate of 9 per cent for no less than 10 years ahead. There were also, she thought, dangers of the cost of the project escalating-the costs of the $28 \mathrm{GeV}$ machine had gone up considerably, and the two small accelerators in Britain had shown escalations of 25 per cent. Science had other calls on the budget, and not everybody agreed that so much of the money should go to high energy physies. Support of the project would have meant that the whole of British high energy physics research would have been based in another country. The Government continued to support another major project at CERN, the intersecting storage rings project, which would itself cost $£ 40$ million. The Government regretted certain decisions that had to be made in the light of devaluation, and "very much hoped that there was no question of a fall in expenditure on scientific research". (Debate, July 24.) 